tion, however, was not available for other causes of death. In the process of random sampling mostly interior villages were chosen, where qualified medical practitioners were generally not available.

A shortcoming of the present analysis may be that the mortality rates were not adjusted for socioeconomic status. Nevertheless, only a small percentage of the target population could be classed as not being poor and therefore, unless the numbers in some categories are small, the confounding effect (if any) would not cause any appreciable difference. The numbers were small for tobacco chewers and multiple users for men and chewing and other usage for women.

Bidi smoking and chewing tobacco with betel leaf are known to carry a $30-50^{\circ}$ higher risk of mortality. ${ }^{4}{ }^{5}$ Thus tobacco usage appears to be injurious to health in any form and more so in the form of $r(v e r s e$ chutta smoking.
This study was supported entirely by the funds from the National Institutes of Health, USA, under PL 480 research agreement No 01-022-N. The authors thank Dr H T Shah for field work.

\section{References}

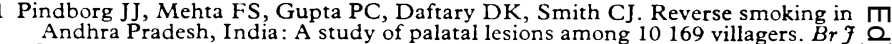
Andhra Pradesh, India:

2 Quigley LF, Shklar G, Cobb CM. Reverse cigarette smoking in Caribbeans: clinical, histologic, and cytologic observations. 7 Am Dent Ass 1966:72:867-73. Gupta PC, Mehta FS, Daftary DK. et al. Incidence rates of oral cancer and natural history of oral precancerous lesions in a 10-year follow-up study of 7 Indian Villagers. Community Dent Oral Epidemiol 1980;8:287-333.

4 Gupta PC, Mehta FS, Irani RR. Comparison of mortality rates among bidi smokers and tobacco chewers. Ind f Cancer 1980;17:149-152.

Gupta PC, Bhonsle RB, Mehta FS, Pindborg J\}. Mortality experience in relation to tobacco habits from a 10-year follow-up study in Ernakulam district, Kerala. Int $\mathcal{F}$ Epidemiol (in press).

(Accepted 21 fune 1984)

\title{
Mechanism of polyuria and natriuresis in atrioventricular nodal tachycardia
}

\author{
R CANEPA-ANSON, M WILLIAMS, J MARSHALL, T MITSUOKA, S LIGHTMAN, R SUTTON
}

\begin{abstract}
A woman with tachycardia associated with polyuria was investigated. Electrophysiological analysis showed that the tachycardia was an atrioventricular nodal re-entrant tachycardia. Programmed stimulation was then used to provoke and sustain the tachycardia for 40 minutes. Polyuria, with an appreciable increase in free water clearance, was observed. This was associated with reduction in plasma and urinary arginine vasopressin concentrations. Appreciable natriuresis also developed.

These results support the hypothesis that the polyuria with increased free water clearance and the natriuresis occurring during sustained tachycardia in man are due to inhibition of secretion of vasopressin and the release of natriuretic factor.
\end{abstract}

\section{Introduction}

The association between paroxysmal tachycardia and polyuria is well recognised and has been reported to occur in $20 \%$ to $50 \%$ of patients with these arrhythmias. ${ }^{12}$ Neither the reason why only a minority of these patients develop polyuria nor the

Departments of Medicine and Cardiology, Westminster Hospital and Charing Cross and Westminster Medical School, London SW1P 2AP

$R$ CANEPA-ANSON, MRCP, senior registrar in general medicine and cardiology

$M$ WILLIAMS, MRCP, lecturer in medicine

J MARSHALL, MB, BS, senior house officer in medicine

T MITSUOKA, MD, research fellow in cardiology

$S$ LIGHTMAN, MRCP, reader in medicine

R SUTTON, FRCP, consultant cardiologist

Correspondence to: Dr S Lightman, Department of Medicine, Westminster Hospital, London.

Requests for reprints to: Dr R Canepa-Anson, Department of Cardiology, Westminster Hospital, London. exact mechanism producing the polyuria is known, although the observed changes in urine composition suggest that the diuresis is attributable to a reflex inhibition of release of arginine $\vec{\bullet}$ vasopressin induced by an increase in atrial stretch receptor activity during tachycardia. ${ }^{13}$

We determined the characteristics of tachycardia in a patient with paroxysmal supraventricular tachycardia and polyuria during elective electrophysiological investigation. After completion of the clinical investigation programmed extrastimuli were used to provoke and sustain the tachycardia so as to permit simultaneous determination of its haemodynamic consequences, the changes in plasma and urinary concentrations of vasopressin, plasma renin activity, and urine flow, osmolality, and electrolyte composition.

\section{Patient and methods}

A 55 year old woman with a 10 year history of palpitations was admitted for investigation because of attacks of increasing frequency and severity. The paroxysmal tachycardia was described as being fast and regular and, if prolonged for more than about 20 minutes, was accompanied by profuse polyuria. She had mild effort angina, $N$ and the tachycardia was sometimes associated with mild anginal pain. She was otherwise fit.

Physical examination yielded normal results apart from showing labile hypertension, with recorded blood pressures ranging from $220 / 120 \mathrm{~mm} \mathrm{Hg}$ to $140 / 90 \mathrm{~mm} \mathrm{Hg}$. The chest radiograph, electrocardiogram, and results of routine tests of haematology and bio- $O$ chemistry were normal. Regular supraventricular tachycardia (170 beats/min) was recorded during an attack of palpitations. Subsequent cardiac catheterisation and angiography confirmed normal left ventricular function. Coronary angiography showed a single $70 \%$ stenosis in the midportion of the left anterior descending coronary artery. The bicycle exercise stress test yielded negative results for both angina and 12 lead electrocardiographic changes at a maximum workload of 130 watts, with a peak heart rate of 150 beats/min and blood pressure of $255 / 85 \mathrm{~mm} \mathrm{Hg}$.

Cardiac electrophysiology-Routine electrophysiological investigation of tachycardia, without premedication, was done using standard multiple simultaneous intracardiac and extracardiac recordings. Programmed cardiac stimulation was used to provoke the tachycardia.

Haemodynamics - Right atrial, pulmonary artery, and pulmonary $\stackrel{P}{P}$ wedge pressures were measured via a right atrial catheter and a 
Swan-Ganz catheter in the pulmonary artery. Systemic blood pressure was also recorded.

Analysis of blood and urine samples-Blood samples of $20 \mathrm{ml}$ were taken at intervals of 10 minutes from the right atrial catheter into chilled lithium-heparin tubes. After centrifugation at $2800 \mathrm{rpm}$ for 10 minutes at $4^{\circ} \mathrm{C}$ plasma was separated. Then $1 \mathrm{ml}$ was used for measurement of plasma sodium concentration and osmolality (Osmomat 030, Gonotec, Berlin), and the remainder was stored at $-20^{\circ} \mathrm{C}$ for measurement of hormone concentrations. Arginine vasopression concentration was determined by radioimmunoassay of extracted $2 \mathrm{ml}$ samples. ${ }^{4}$ The detection limit for the assay is $0.25 \mathrm{pmol} / 1$ $(27 \mathrm{pg} / 100 \mathrm{ml})$. Coefficients of variation of control samples $(2 \mathrm{fmol}$ $(2.2 \mathrm{fg})$ ) were $6 \%$ (intra-assay) and $17 \%$ (interassay). Plasma renin activity was determined by radioimmunoassay of angiotensin I generated on incubation of plasma for two hours at $37^{\circ} \mathrm{C}$ in the presence of converting enzyme inhibitors. ${ }^{5}$ Urine was collected over periods of 10 minutes in a urinometer via a urinary catheter that had been inserted in the ward immediately before the investigation. Measurements were made of volume, osmolality, and sodium, potassium, and vasopressin concentrations.

Protocol-Standard measurements of sinus node function and intracardiac conduction were obtained, followed by programmed cardiac stimulation. After characterisation of the tachycardia, baseline measurements of pressures, hormone concentrations, and urine were made in sinus rhythm. The tachycardia was then started again and sustained for 40 minutes. Measurements were taken every 10 minutes throughout the tachycardia and for 30 minutes afterwards.

\section{Results}

Cardiac electrophysiology-The only abnormality found was dual atrioventricular nodal pathways, which were associated with atrial echo beats. Burst atrial pacing at 180 beats/min induced the paroxysmal tachycardia, the mechanism of which was shown to be atrioventricular nodal re-entry.

Haemodynamics-Mean pulmonary wedge pressure doubled from 6.5 to $13.0 \mathrm{~mm} \mathrm{Hg}$, but mean right atrial pressure did not change (table I). Blood pressure, which was known to be labile in this patient (between $140 / 90$ and $210 / 120 \mathrm{~mm} \mathrm{Hg}$ on previous occasions) was, not surprisingly, raised during the control period and rose further during the induced tachycardia. Despite this combination of tachycardia and raised arterial blood pressure she remained asymptomatic throughout the study. During the course of the sustained tachycardia there was a gradual fall in mean pulmonary wedge pressure. After the tachycardia had stopped mean pulmonary wedge pressure was lower than the control measurement.

TABLE I-Haemodynamic values before, during, and after induced tachycardia of $\mathbf{4 0}$ minutes' duration

\begin{tabular}{|c|c|c|c|c|}
\hline $\begin{array}{l}\text { Time } \\
(\min )\end{array}$ & $\begin{array}{c}\text { Heart rate } \\
\text { (beats } / \mathrm{min} \text { ) }\end{array}$ & $\begin{array}{c}\text { Mean ("systolic" } \\
\text { wave) pulmonary } \\
\text { wedge pressure } \\
(\mathrm{mm} \mathrm{Hg})\end{array}$ & $\begin{array}{l}\text { Mean "systolic" } \\
\text { wave) right atrial } \\
\text { pressure } \\
(\mathrm{mm} \mathrm{Hg})\end{array}$ & $\begin{array}{c}\text { Blood } \\
\text { pressure } \\
(\mathrm{mm} \mathrm{Hg})\end{array}$ \\
\hline $\begin{array}{r}0 \\
5 \\
35 \\
50\end{array}$ & $\begin{array}{r}63^{*} \\
170^{+} \\
170^{+} \\
76^{*}\end{array}$ & $\begin{aligned} 6 \cdot 5 & (10) \\
13 & (22) \\
9 & (13) \\
4 & (6)\end{aligned}$ & $\begin{array}{ll}3 \cdot 5 & (5) \\
4 & (7) \\
4 & (8) \\
3 & (4)\end{array}$ & $\begin{array}{l}150 / 110 \\
200 / 120 \\
200 / 140 \\
150 / 110\end{array}$ \\
\hline
\end{tabular}

* Sinus rhythm.

+ Nodal tachycardia.

Plasma and urine-During the induced tachycardia there was an appreciable decrease in both plasma vasopressin concentration, from 1.0 to $0.5 \mathrm{pmol} / \mathrm{l}(108$ to $54 \mathrm{pg} / 100 \mathrm{ml}$ ( (normal range $1 \cdot 0-2.5 \mathrm{pmol} / 1$ $(108-270 \mathrm{pg} / 100 \mathrm{ml})$ ), and urinary excretion of vasopressin, from 41.0 to $2.8 \mathrm{fmol} / \mathrm{min}(44.5$ to $3.0 \mathrm{pg} / \mathrm{min}$ ) (normal range $20-50 \mathrm{fmol} /$ $\min (21 \cdot 7-54 \mathrm{pg} / \mathrm{min})$ ) (figure). At the same time urine flow increased from 1.3 to $13.0 \mathrm{ml} / \mathrm{min}$ and urinary osmolality fell from 585 to $115 \mathrm{mmol}(\mathrm{mosmol}) / \mathrm{kg}$ (table II), giving a rise in free water clearance from -1.4 to $7.8 \mathrm{ml} / \mathrm{min}$. Urinary excretion of sodium increased from 0.1 to $1.43 \mathrm{mmol}(\mathrm{mEq}) / \mathrm{min}$, representing an increase in sodium clearance from 0.7 to $9.8 \mathrm{ml} / \mathrm{min}$. There was a moderate rise in plasma renin activity from 1.2 to $1.86 \mathrm{nmol}$ angiotensin $\mathrm{I} / \mathrm{l} / \mathrm{h}(1.59$ to $2.42 \mathrm{ng}$ angiotensin $\mathrm{I} / \mathrm{ml} / \mathrm{h}$ ). There was no significant change in either plasma osmolality or plasma sodium concentration during the study. Urinary potassium excretion also increased from a basal rate of 0.05
TABLE II-Plasma and urinary concentrations and osmolality measured at intervals of 10 minutes during induced tachycardia of $\mathbf{4 0}$ minutes' duration and a recovery period of 30 minutes

\begin{tabular}{|c|c|c|c|c|c|c|}
\hline \multirow{2}{*}{$\begin{array}{l}\text { Time } \\
(\min )\end{array}$} & \multicolumn{3}{|c|}{ Plasma } & \multicolumn{3}{|c|}{ Urine } \\
\hline & $\begin{array}{r}\text { Osmolality } \\
\cdot(\mathrm{mmol} / \mathrm{kg})\end{array}$ & $\underset{(\mathrm{mmol} / \mathrm{l})}{\text { Sodium }}$ & $\begin{array}{c}\text { Renin } \\
\text { activity } \\
(\mathrm{nmol} / \mathrm{l} / \mathrm{h})\end{array}$ & $\begin{array}{l}\text { Flow rate } \\
(\mathrm{ml} / \mathrm{min})\end{array}$ & $\begin{array}{l}\text { Osmolality } \\
(\mathrm{mmol} / \mathrm{kg})\end{array}$ & $\begin{array}{c}\text { Sodium } \\
\text { (mmol/ } \\
\text { min) }\end{array}$ \\
\hline $\begin{array}{r}0 \\
10 \\
20 \\
30 \\
40 \\
50 \\
60 \\
70\end{array}$ & $\begin{array}{l}288 \\
286 \\
290 \\
287 \\
287 \\
285 \\
285 \\
288\end{array}$ & $\begin{array}{l}138 \\
138 \\
141 \\
137 \\
143 \\
146 \\
141 \\
142\end{array}$ & $\begin{array}{l}1.22 \\
1.43 \\
1.51 \\
1.76 \\
1.78 \\
1.86 \\
1.14 \\
1.22\end{array}$ & $\begin{array}{r}1 \cdot 3 \\
4 \cdot 0 \\
3 \cdot 0 \\
9 \cdot 0 \\
12 \cdot 0 \\
13 \cdot 0 \\
8 \cdot 0 \\
2 \cdot 0\end{array}$ & $\begin{array}{l}585 \\
458 \\
301 \\
163 \\
127 \\
115 \\
128 \\
150\end{array}$ & $\begin{array}{l}0.10 \\
0.16 \\
0.12 \\
0.40 \\
0.58 \\
1.43 \\
0.98 \\
0.11\end{array}$ \\
\hline
\end{tabular}

Conversion: SI to traditional units-Osmolality: $1 \mathrm{mmol} / \mathrm{kg}=1 \mathrm{mosmol} / \mathrm{kg}$. Sodium: $1 \mathrm{mmol} / 1=1 \mathrm{mEq} / \mathrm{l}$. Renin activity: $1 \mathrm{nmol}$ angiotensin $\mathrm{I} / \mathrm{l} / \mathrm{h} \approx 1.3 \mathrm{ng}$ angiotensin $\mathrm{I} / \mathrm{ml} / \mathrm{h}$.
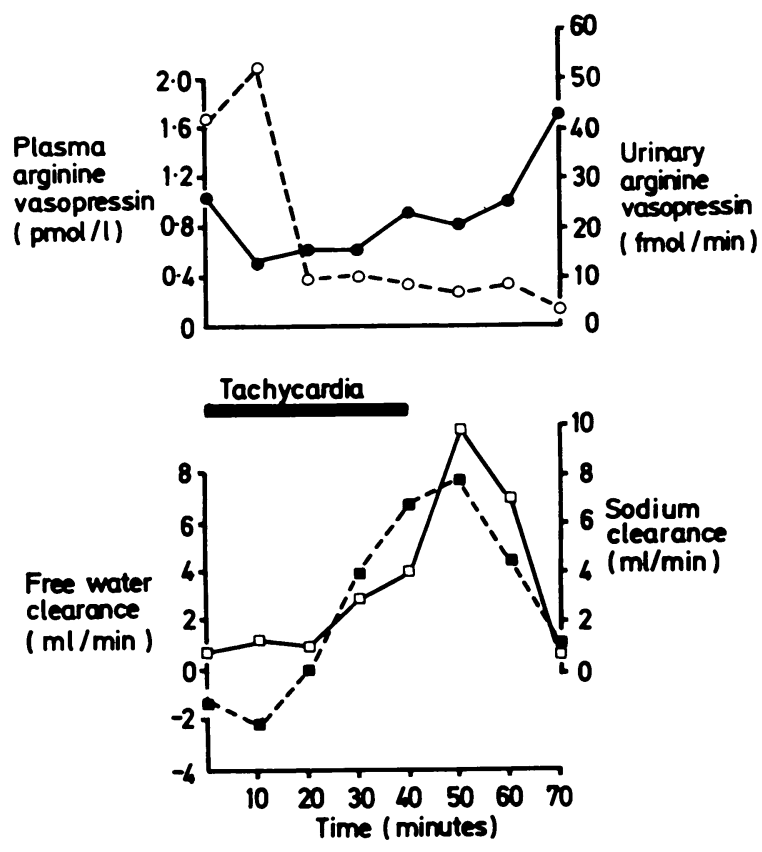

Changes in plasma (- - ) and urinary (- - $\left.-_{--}\right)$vasopressin concentrations (above) and in free water clearance (- - - -) and sodium clearance ( $-\square-$ ) (below) during 40 minutes of induced nodal tachycardia and a subsequent recovery period of 30 minutes.

Conversion: SI to traditional units-Vasopressin: $1 \mathrm{pmol} / 1 \approx$ $108 \mathrm{pg} / 100 \mathrm{ml}$.

$\mathrm{mmol}(\mathrm{mEq}) / \mathrm{min}$ to a maximum of $0.43 \mathrm{mmol} / \mathrm{min}$. During the recovery period all the above variables returned towards their original values.

\section{Discussion}

We have shown, for the first time in man, suppression of plasma and urinary vasopressin after the onset of artificially induced tachycardia, which was associated with a doubling of mean pulmonary wedge pressure and polyuria, with both increased free water clearance and appreciable natriuresis. Henry et al in 1956 were the first to attribute to left atrial receptors a role in the control of the release of vasopressin. ${ }^{6}$ Several groups of workers have subsequently confirmed that an increase in left atrial pressure achieved by inflating a balloon in the left atria of dogs inhibits the release of vasopressin and causes diuresis. ${ }^{7} 8$ In addition, Boykin et al have shown that rapid atrial pacing in dogs causes diuresis and suppression of plasma vasopressin release, effects which are abolished by bilateral cervical vagotomy. ${ }^{\circ}$ In these animals, therefore, atrial stretch receptors with vagal afferents probably tonically inhibit secretion of vasopressin and this inhibition can probably be 
augmented by increasing left atrial pressure. Atrial receptors may also regulate secretion of vasopressin in man. Both nonhypotensive haemorrhage and orthostasis result in release of vasopressin, and vagal afferents from atrial receptors are likely to play a part in this response. ${ }^{10}$ Despite the major physiological importance of these control mechanisms data relating changes in left atrial pressure to plasma concentrations of vasopressin have not been reported in man.

In the present study water diuresis occurred after reduction of plasma vasopressin concentration to half its control value ( 20 minutes after the induction of the tachycardia) and was accompanied by the virtual disappearance of urinary vasopressin. Polyuria has only been reported in those paroxysms lasting longer than 20 minutes, ${ }^{12}$ which is roughly twice the half life of plasma vasopressin. The time course and magnitude of the reduction in plasma and urinary vasopressin observed in this study support the hypothesis that inhibition of secretion of vasopressin is the cause of the water diuresis associated with prolonged paroxysms of tachycardia in man.

Appreciable natriuresis also occurred, at the same time as the water diuresis. This was not due to a reduction in plasma renin activity, as this rose slightly. Increased renal perfusion pressure normally results in the suppression of plasma renin activity, and this effect had probably been overridden by a combination of increased sympathetic activity and the minor degree of volume contraction. Natriuresis accompanying the water diuresis of the polyuria associated with tachycardia was first reported by Wood. ${ }^{1}$ Natriuresis accompanying polyuria has also been documented in subjects with raised left atrial pressure resulting from immersion. ${ }^{11}$

The mechanism for these natriuretic changes is not understood, but recently there has been mounting interest in the proposed role of natriuretic peptides within the atria themselves. Cells in the atria contain storage granules similar to those known to secrete peptide hormones. ${ }^{12}$ Infusion of rat atrial extract, but not ventricular extract, results in considerable natriuresis, ${ }^{13}$ apparently by inhibiting sodium resorption in the distal nephron. Purification and analysis of atrial natriuretic polypeptides has been achieved both in experimental animals ${ }^{14}$ and in man, ${ }^{15}$ and this peptide would seem to be the most likely candidate for causing the natriuresis observed in this study. It is, however, important to emphasise that we cannot measure the contribution of the increase in renal perfusion pressure alone to the considerable increase in sodium output seen in our patient. There was also a relatively smaller kaliuresis associated with the tachycardia. A similar effect has been reported after infusion of atrial extract in rats. ${ }^{13}$

The conditions required for the association of polyuria with paroxysmal tachycardia may be inferred from Wood's clinical observations, ${ }^{1}$ laboratory studies, ${ }^{9}$ and from our own findings, and would appear to be as follows: the tachycardia must be faster than 120 beats/min and must be sustained for a minimum of 20-30 minutes, which is equivalent to at least twice the half life of plasma vasopressin; mean left atrial pressure should rise roughly twofold, from low normal to around the upper limit of the normal range, with stimulation of the vagally innervated left atrial stretch receptors. Systolic left ventricular function must be good, but diastolic relaxation should be mildly abnormal so that the tachycardia causes an adequate but not excessive increase in left atrial pressure.

The absence of nodal tachycardia from both Wood's and Luria's lists of tachyarrhythmias associated with polyuria ${ }^{12}$ is probably only a reflection of the difficulties of accurate classification of supraventricular tachycardias from the electrocardiogram alone. Nowadays electrophysiological investigation is used to provide accurate classification of the mechanisms of difficult supraventricular tachycardias.

Why the many cardiac conditions in which there are much greater increases in mean left atrial pressure are not associated with suppression of vasopressin release and polyuria is not known, though several possible mechanisms may be suggested. Of great interest in this respect is Wood's finding that the development of acute pulmonary oedema during the tachycardia invariably inhibited the polyuria and that the polyuria then often occurred instead during recovery after the end of the paroxysm. ${ }^{1}$ The implication of this observation is that pathophysiological mechanisms exist that can override the inhibitory effects of the left atrial vagal afferents on secretion of vasopressin. There is no a priori reason why such mechanisms might not be operative in chronic heart failure.

In conclusion, we have shown that standard electrophysiological methods may be used to reproduce, under controlled conditions, the "tachycardia-polyuria syndrome" in man and may thus provide a technique for the study of the mechanisms of inhibition of vasopressin secretion and of release of natriuretic factor. By these means we have shown that both the size and time course of the measured falls in plasma and urinary vasopressin concentrations were consistent in our patient with the observed polyuria and increase in free water clearance.

We thank Dr P R Fleming for permission to study and report on his patient; and Dr P H Baylis for his kind gift of vasopressin antiserum.

\section{References}

1 Wood P. Polyuria in paroxysmal tachycardia and paroxysmal atrial flutter and

Luria MH. Selected clinical features of paroxysmal tachycardia. $\mathrm{Br}$ Heart $\mathfrak{f}$ $1971 ; 33: 351-7$

3 Gauer $\mathrm{OH}$, Henry JP, Behn C. The regulation of extracellular fluid volume. Ann Rev Ph: siol 1970;32:547-95.

Williams TDM, Carter DA, Lightman SI. Sexual dimorphism in the posterior

pituitary response to stress in the rat. Endocrinology (in press).
5 Boyd GW, Peart WS. Angiotensin immunoassay. In: Page IH, Bumpus FM, eds. Angiotensin. Berlin: Springer-Verlag, 1974:211.

6 Henry JP, Gauer OH, Reeves JL. Evidence of the atrial location of receptors influencing urine flow. Circ Res 1956;4:85-90.

7 Share L. Effects of carotid occlusion and left atrial distension on plasma vasopressin titer. Am $\mathcal{F}$ Physiol 1965;208:219-23.

8 Fater DC, Schultz HD, Sundet WD, Mages JS. Effects of left atrial stretch in cardiac denervated and intact conscious dogs. Am F Physiol 1982;242:H1056-64. 9 Boykin J, Cadnapaphornchai P, McDonald KM, Schrier RW. Mechanism of diuretic 10 Share L. Role of cardiovascular recep estein M, Pins DS, Miller M. Suppr

immersion in normal man. 7 Appl Physiol 1975;38:1038-44.

12 Jamieson JD, Palade GE. Specific granules in atrial cells. $\mathcal{F}$ Cell Biol 1964;23: $151-72$

13 Pollock DM, Banks RO. Effects of atrial extract on renal function in the rat. Clin Sci 1983;65:47-55.

14 Currie MG, Geller DM, Cole BR, et al. Purification and sequence analysis of bioactive atrial peptides (atriopeptins). Science 1984;221:71-3.

15 Kangawa $\mathrm{K}$, Matsuo $\mathrm{H}$. Purification and complete amino acid sequence of a-human atrial natriuretic polypeptide (a-h ANP). Biochem Biophys Res

(Accepted 30 fuly 1984)

\section{ONE HUNDRED YEARS AGO}

The recent annual Trades' Union Congress, held in Aberdeen, of necessity devoted the greater part of the week, during which its meetings were held, to the discussion of questions affecting trade, but it did good service to the country generally in directing attention to the condition of matters that exist in the chain- and nail-making shops of South Staffordshire and East Worcestershire. In these counties it is the custom to employ both male and female labour in the work of forging nails and chains, but no steps are taken to separate the sexes, and women and girls of tender years work in a more than semi-nude condition among men and boys equally little clad. As a consequence, it is found that the greatest immorality, depravity, and pauperism prevails, and those who have personally visited the districts, have come away shocked by the scenes to be witnessed in this branch of labour. From the speeches made on the subject, we gather that this state of matters has been referred to before, and that the facts brought forward are already embodied in the report of some Commission. Be that as it may, the Congress has acted wisely in again bringing them forward, for it is clear they demand some remedial legislation, and that, without in any way encroaching on the sphere of female labour, there might be introduced some amendment of the Factory and Workshops Act, which would check the continuance of this present system, and put an end to this indescribable immodesty and immorality. (British Medical fournal 1884;ii:578.) 